\title{
RELATIONSHIP OF EMPLOYMENT OPPORTUNITIES WITH EDUCATION NEEDS IN ARISAN MUSI VILLAGE, MUARA BELIDA DISTRICT
}

\author{
Kms. Rahmat Abdul Ghofur ${ }^{1 *}$, Thoriq Habsyi², Dinda Cici Aulia ${ }^{3}$, \\ Rizki Anantha Emdardi ${ }^{4}$, Maya Panorama ${ }^{5}$ \\ 1,2,3,4,5 UIN Raden Fatah Palembang \\ Email: 1920602140@radenfatah.ac.id*
}

\begin{abstract}
Educational demands driven by educational growth have grown the economy of the people of Arisan Musi Village, Muara Belida District, Muara Enim Regency by increasing job opportunities. The allocation of knowledgeable human resources is the beginning of economic growth. education in Arisan Musi Village is quite good compared to previous years. The descriptive analysis aims to explain the development of the education level of the people of Arisan Musi Village, Muara Belida Regency, South Sumatra Province. Education can improve the quality of human resources which in turn can help foster public understanding of development. Therefore, to have the ability to participate in society, it is necessary to increase human resources through education. There are various aspects that can improve the quality of human resources such as health, education, and so on. With many people starting to migrate and work in better jobs than depending on plantations in Arisan Musi Village. The quality of human resources is the foundation for successful development. So that internal and external factors that affect the quality of human resources become better, and village growth becomes better. Good education can also produce good human resources. These quality human resources can increase productivity at work so that the opportunity to work is higher and the economic situation is getting better in the village of Arisan Musi. Because if the quality of human resources is good, it can support the development process of an area to develop into a growth center.
\end{abstract}

Keywords: Education, Job Opportunities, Human Resources, Descriptive Analysis.

\section{INTRODUCTION}

Human nature as a living being always wants something better. It is a biological and psychological dimension of humans to meet the needs of life in the world. The necessities of life must be human themselves by using certain ways. The demands of meeting these needs cannot always be met easily. The more people who need it, the more limited the sources of fulfillment will be. Limitations that will cause people to think, how to get these needs. The process of thinking and the way humans in an effort to meet the needs of life will become part of the culture of society, including the development of existing science and technology.

Community participation is very important as a forum for conveying aspirations related to development policy priorities that concern their interests. In

\footnotetext{
${ }^{1}$ Student of Raden Fatah State Islamic University Palembang, Faculty of Islamic Economics and Business. ${ }^{2}$ Studentof Raden Fatah State Islamic University Palembang, Faculty of Islamic Economics and Business. ${ }^{3}$ Student of Raden Fatah State Islamic University Palembang, Faculty of Islamic Economics and Business. . ${ }^{4}$ Students of Raden Fatah State Islamic University Palembang, Faculty of Islamic Economics and Business.

${ }^{5}$ Lecturer at Raden Fatah State Islamic University Palembang, Faculty of Islamic Economics and Business.
} 


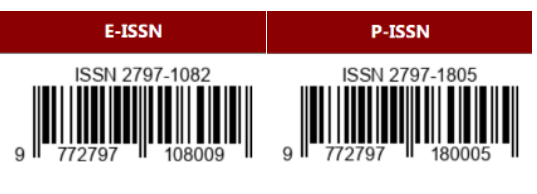

Volume 2 Nomor 1 (Desember 2021 - Februari 2022)

addition, participation also functions as a check and balance (monitoring and balancing) the ongoing development process. The realization of community participation can be done, either individually or in groups, spontaneously or organized, on an ongoing or temporary basis, as well as in other ways that can be done. Community participation in the implementation of regional development is one of the absolute requirements in this era of freedom and openness. Ignoring this factor can lead to a fairly large gap with the development goals themselves, namely the overall effort to improve people's welfare. The process of involving local community participation in the implementation of development projects in the regions/villages is expected to be able to bring about fundamental changes in improving the welfare of rural families ${ }^{6}$.

At this time the problem of job opportunities is a problem of a country, the difficulty of finding work has an impact on social problems where unemployment, depression, and even high poverty levels occur. The existence of workers or laborers for now often comes to the surface, because they demand their rights.

According to the Law of the Republic of Indonesia Number 21 of 2000, it is stated that, for workers or laborers, they are obliged to have a sense of responsibility for a decent and happy life both physically and mentally. Workers or laborers as citizens have the same position under the law, the right to obtain a job and a decent living, express opinions, gather in one organization, and form and become members of a trade union or trade union ${ }^{7}$.

\footnotetext{
${ }^{6}$ Ananta, Aris. 1973. Demographic Characteristics, Population Quality and Economic Development. Jakarta: Demographic Institute, FEUI.
}

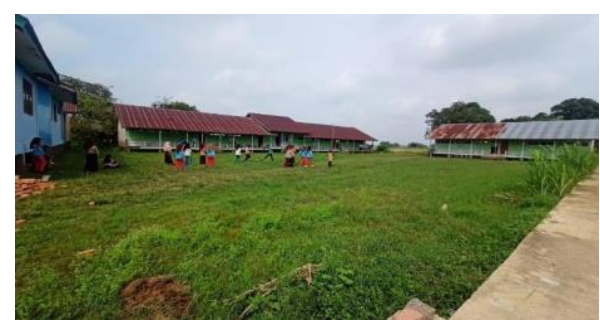

Figure 1. MtsSNurussaadah

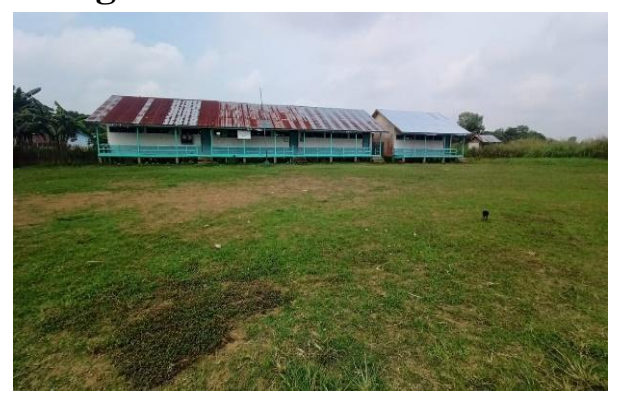

Figure 2. MAS Nurussaada

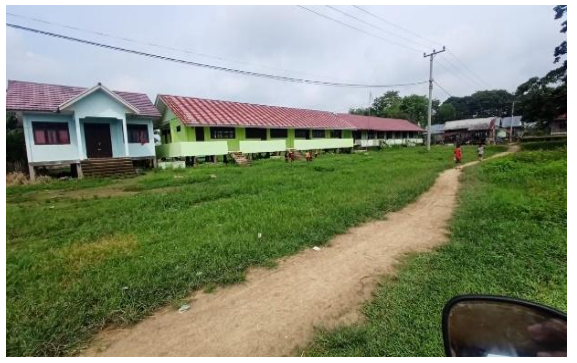

Figure 3. SDN 2 Muara Belida

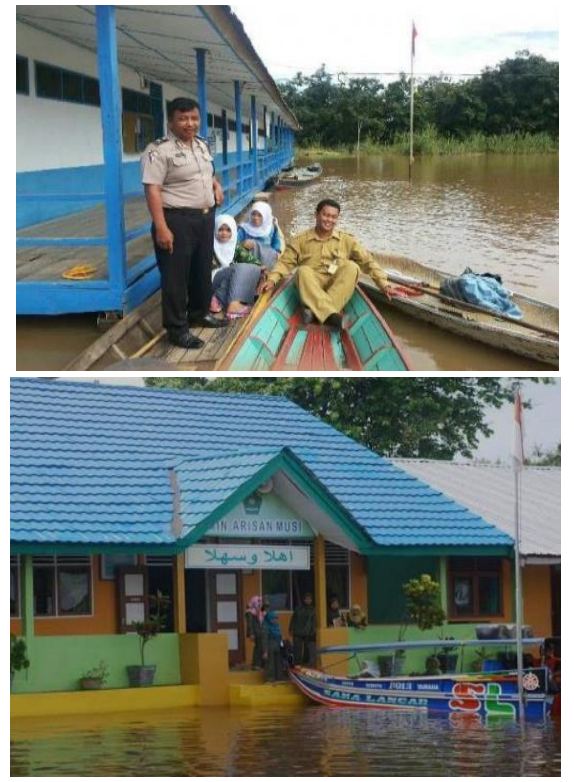

Figure 4. School condition during the flood

${ }^{7}$ Law of the Republic of Indonesia number 21 of 2000. Manpower. 04 August 2000. LN. 2001/ No. 131, TLN NO. 3989, LL SETNEG: 15 HLM. Jakarta 
Based on the picture, the state of education in Arisan Musi village is still relatively lagging, where the distance from the village to the sub-district - the district capital is about 20 kilometers and with an altitude of $<500$ meters above the sea level. Making infrastructure difficult to access and difficult to get help in the event of a flood, for example. However, from year to year the number of ulama from Arisan Musi village is increasing and the economy is getting better. Therefore, it is necessary to conduct research on the level of education that affects job opportunities in Arisan Musi village, Muara Belida district.

\section{LITERATUR REVIEW}

\section{Education}

Level Based on the Law of the Republic of Indonesia number 20 of 2003 article I concerning the national education system, education is a conscious and planned effort to create a learning atmosphere and learning process so that students actively develop their potential to have religious spiritual strength, self-control, personality, intelligence, noble character, and skills needed by himself, society, nation and state. Education is a process that aims to increase skills, knowledge and increase independence and the formation of one's personality (Arfida, 2003:77). It can be concluded from the above understanding that education is a process or effort for individuals to add higher knowledge and understanding that is needed by themselves, society, nation and state.

\section{Educational attainment}

Levels are the stages of education that are determined based on the level of

\footnotetext{
${ }^{8}$ Atmanti, DwiHastarini. 2005. Investment in Human Resources Through Education. Dynamics of
}

development of students, the goals to be achieved, and the abilities developed. According to the 2003 National Education System Law, the levels of formal education consist of basic education, secondary education, and higher education.

\section{The purpose of education}

The function and purpose of national education is in accordance with the Law of the Republic of Indonesia No. 20 of 2003 concerning the National Education System that states that national education functions to develop capabilities and shape the character and civilization of a dignified nation in the context of educating the nation's life, aiming to develop the potential of students to become human beings of faith. and fear God Almighty, have noble character, are healthy, knowledgeable, capable, creative, independent, and become democratic and responsible citizens ${ }^{8}$.

\section{Theory Human Capital}

Resources. The basic assumption of human capital theory is that one can increase income through increased education. The theory can be explained that, each additional year of schooling means increasing one's work ability and income level, but on the other hand delaying income receipts for one year to attend school and hoping to increase income by increasing education (Mankiw, 2006:57).

Education has an influence on economic growth because education plays a role in increasing labor productivity. This theory assumes that community growth is determined by individual productivity, if everyone has a higher income due to higher

Development (online), Vol. 2 No. 1,

(journal.uny.ac.id) accessed 10 November 2021 
education, the community's economic growth can be supported (Mankiw, 2006:68).

Human Capital theory views formal education as an investment, both for individuals and society, in relation to employment opportunities that are more open to those with higher levels of education. This is because in general the scarcity rate of college graduates is also more accurate, so there is less competition for suitable jobs. Job opportunities for college graduates are more open, so theoretically the level of movement in this group tends to be smaller than the group with low education, but job opportunities will be narrower with the number of college graduates ${ }^{9}$.

The level of education also affects the level of income, those with higher education earn higher incomes. Basicallythe higher income of those with higher education, is a direct result of a more expensive investment in their higher education, but of something complex. The role of formal education to improve skills has been recognized by all countries. Education As stated by Todaro (2010), not only aims to increase knowledge and skills for workers for development purposes, but formal education can also provide values, ideals, attitudes and aspirations that are directly or indirectly related to development interests ${ }^{10}$.

\section{Manpower}

Manpower is a population who has entered working age, both those who are

\footnotetext{
${ }^{9}$ Fattah, Anang. 2004. Foundations of Educational Management. Rosdakarya Youth: Jakarta

${ }^{10}$ Mulyadi. 2008. Economics of Human Resources in a Development Perspective. PT. Rajawali Press: Jakarta

${ }^{11}$ MT Rionga\& Yoga Firdaus, 2007 in http://muawanahcius.

blogspot.com/2013/04/pengertian - labor-force.htm
}

already working and actively looking for work, who are still willing and able to do work $^{11}$. Based on Law No. 13 of 2003, labor is anyone who is able to do work to produce goods and services, both to meet the needs of themselves and the community. Labor is a very important factor of production for every country, in addition to natural factors and capital factors. Because even though a country has large natural resources and capital, it still needs labor as a factor of production. To improve the quality of the workforce can be done in the following ways.

- Workforce Training.

Manpower training is the entire activity to provide, obtain, improve, and develop competence, productivity, discipline, attitude, and work ethic at a certain level of skill and expertise in accordance with the level and qualification of the position or job ${ }^{12}$.

- Apprenticeship.

Apprenticeship is part of the job training system that is held in an integrated manner between training in training institutions and working directly. The apprenticeship is under the guidance and supervision of instructors or workers who are experienced in the production process of goods/services in the company ${ }^{13}$.

\section{METHODOLOGI}

type of research in this study is descriptive, descriptive research is divided

\footnotetext{
12 MT Rionga\& Yoga Firdaus, 2007 in http://muawanahcius.

blogspot.com/2013/04/pengertian- labor-force.htm

${ }^{13}$ Sumarsono, Sonny. 2003. Economics of Human Resource Management and Employment. Jakarta: GrahaIlmu.
} 
into two objectives, namely a) research that aims to determine the development of certain facilities, dissemination a symptom, or the frequency of occurrence of a particular social phenomenon, and b) research that aims to describe in detail a particular social phenomenon ${ }^{14}$. The descriptive analysis aims to explain the development of the education level of the people of Arisan Musi Village, Muara Belida Regency, South Sumatra Province ${ }^{15}$.

The data used in this training is primary data obtained from the information provider directly and has not been processed. By conducting direct research in the field, and asking various questions to respondents. With this research, it is hoped that the government will pay more attention and provide targeted solutions.

\section{RESULTS AND DISCUSSION}

\section{General description of the research area}

Among aspects of education are considered to have a fairly important role in creating and improving the quality of our community resources. Therefore, to have the ability to participate in the community, it is necessary to increase human resources through the education sector. Broad access to education will accelerate the high level of public education, which in turn will enable the community to participate in development. Education can improve the quality of human resources which in turn can help foster public understanding of development. The quality of human resources is the foundation for successful development.
As the religion of rahmatanlilalamin, Islam regulates its adherents to act and behave well in order to pray and seek lawful sustenance. One of them works in various fields such as agriculture, animal husbandry, and so on. Here knowledge is very influential in getting a job, both knowledge from formal and non-formal education, especially formal education, people usually get more job opportunities. For such reasons, we indirectly demand education to get job opportunities.

The fact says that our education still leaves many problems such as the lack of proper and equitable education in all levels of society. There are still many village children who are forced to not be able to receive formal education for various reasons, namely economic and social, the atmosphere is not conducive with the lack of educational support facilities, not to mention geographical constraints, many islands or difficult areas. accessible to education. However, steps to improve education will always be pursued in stages and comprehensively, starting from increasing the allocation of the education budget, education programs such as BOS, free school policies in several regions, teacher certification allowances, the Teacher and Lecturer Law which signals the welfare of teachers. will be improved and so on. The various efforts that have been made are expected to spur the improvement of education both in quality and quantity although it is still not sufficient, however, the improvement efforts are expected to continue

\footnotetext{
${ }^{15}$ Djarwanto. 1993. Research Methods. Gramedia Main Library : Jakarta.

${ }^{14}$ Heri Junaidi.2018. Discovery-Based Research Methods.Palembang: Rafah Press. Page 44
} 
to encourage the improvement of education in Indonesia ${ }^{16}$.

In this study, Arisan Musi Village, which is one of the villages in Muara Belida District, Muara Enim Regency. Arisan Musi village is 20 kilometers from the capital city. The topography of Arisan Musi Village flows through a river and is located at an altitude of $<500$ landmass from seawater settlements.

\section{Education}

\section{Number of Students in Arisan Musi} Village

Table 1

\begin{tabular}{|c|c|}
\hline Education & Student \\
\hline MIN 5 Muara Enim & 218 \\
\hline SDN 2 Muara Belida & 38 \\
\hline MTSS Nurussaadah & 116 \\
\hline MAS Nurussaadah & 158 \\
\hline \multicolumn{2}{|c|}{ Data Source: Based on data }
\end{tabular}

distributed by teachers in Arisan Musi Village

From table 1, it can be seen that the education level of the community in Arisan Musi village is quite good, where for high school education / equivalent 158 people and MIN 218 people. While the lowest at the level of basic education / equivalent amounted to 36 people.

According to the respondent Mr. Kms. MohdShoddiq, education in Arisan Musi Village is quite good compared to previous years. In the past, the paradigm of the Arisan Musi village community considered higher education useless because they would return to gardening, after the ulama from the Arisan Musi village began to emerge and indirectly the paradigm began to fade. With many

\footnotetext{
${ }^{16}$ Armawan, I KadekKrisna\&Kesumajaya, I Wayan Wita. (2013). ANALYSIS OF COMPETITIVENESS AND FACTORS AFFECTING INDONESIA'S
}

people starting to migrate and work in better jobs.

Then depending on plantations in Arisan Musi Village. Gradually the village of Arisan Musi began to develop with the average level of education of the generation there being an average of high school and equivalent and many ulama from the village began to help with education there. Good education can also produce good human resources. So how important is education in producing quality and competitive resources to get job opportunities. These quality human resources can increase productivity at work so that the opportunity to work is higher and the economic situation is getting better in the village of Arisan Musi.

The existence of internet access makes society more advanced. So that internal and external factors that affect the quality of human resources become better, and village growth becomes better. Because if the quality of human resources is good, it can support the development process of an area to develop into a growth center.

The allocation of knowledgeable human resources is the beginning of economic growth. As the economy grows, the accumulation of new capital is needed to keep the economy growing. In other words, human resources who receive education, especially formal education, are an absolute requirement for higher job opportunities and creating economic growth. The relationship between educational demands and job opportunities has a relationship, because without continuous education, adequate economic development

EXPORTS OF PROCESSED WOOD TO THE UNITED STATES. E-JOURNAL OF UDAYANA UNIVERSITY DEVELOPMENT ECONOMICS, 2 [6]: 306-313. 
will not be achieved, such as getting a better job.

With several factors that affect HR, making HR in Arisan Musi village more qualified and having a positive impact on Arisan Musi village, the younger generation of Arisan Musi is more updated, especially in the field of employment, ranging from manuals to the like. now they have started to use technology such as machines for activities in the field. At first the people only made rice fields their main job, now it can be said that making money is easier. Such as odd jobs, raising livestock, wandering, and for those who have taken education, they can become teachers so that their generation is better.

\section{CONCLUSION}

Educational demands driven by educational growth have grown the economy of the people of Arisan Musi Village, Muara Belida District, Muara Enim Regency by increasing job opportunities.

\section{Suggestions}

To maintain and develop the welfare level of Arisan Musi village with assistance from the government to support the Arisan Musi village community, Muara Belida Regency with assistance such as better village infrastructure, infrastructure assistance for school buildings, health centers or hospitals and so on to improve the quality of community resources in Arisan Musi Village, Muara Belida District, Muara Enim Regency.

\section{REFERENCE}

Ananta, Aris. 1973. Demographic Characteristics, Population Quality and Economic Development. Jakarta: Demographic Institute, FEUI.
Armawan, I KadekKrisna\&Kesumajaya, I Wayan Wita. (2013). Analysis Of Competitiveness And Factors Affecting Indonesian Processed Wood Exports To The United States. E-Journal Of Development Economicsuniversity

UDAYANAAtmanti, DwiHastarini. 2005. Investment in Human Resources Through Education. Dynamics of Development (online), Vol. 2 No. 1, (journal.uny.ac.id) accessed 10 November 2021

Djarwanto. 1993. Research Methods. Gramedia Main Library : Jakarta.

Fattah, Anang. 2004. Educational Management Foundation.

Youth.Rosdakarya: Jakarta

Heri Junaidi.2018. Discovery-Based Research Methods.Palembang: Rafah Press. Page 44

MT Rionga\& Yoga Firdaus, 2007 in http://muawanahcius.

blogspot.com/2013/04/pengertian labor-force.htm

MT Rionga\& Yoga Firdaus, 2007 in http://muawanahcius.

blogspot.com/2013/04/pengertianlabor-force.htm

Mulyadi. 2008. Economics of Human Resources in a Development Perspective. PT. Rajawali Press: Jakarta Sumarsono, Sonny. 2003. Economics of Human Resource Management and Employment. Jakarta: GrahaIlmu.

Law of the Republic of Indonesia number 21 of 2000. Manpower. 04 August 2000. LN. 2001/ No. 131, TLN NO. 3989, LL SETNEG: 15 HLM. Jakarta 